\title{
The Influence of Technological Progress on the Future Development of Design Teaching
}

\author{
Yong $\mathrm{Li}^{1,2}$ Mingming Zong ${ }^{1, *}$ \\ ${ }^{1}$ Beijing Institute of Technology, Zhuhai, Zhuhai, Guangdong, China \\ ${ }^{2}$ Bangkokthonburi University, Bangkok, Thailand \\ *Corresponding author. Email: 69771402@qq.com
}

\begin{abstract}
This article studies the close developmental relationship between art and design in the origin and development of art, and social relations with differences, especially the thinking about the teaching phenomenon that easily leads to thinking conflicts in the process of teaching development. By sorting out time clues, it compares and studies the differences and connections between art and design teaching in origin, process, and goals, and combines literature research, typical case analysis, and teaching experience to explain that design should serve the needs of industrial development, and teaching design should clarify the relationship between art and design. The argument illustrates the impact of new technology development on social morality, self-cognition, and social relations in design education, and emphasizes that the relationship between art, design, and technology in future design teaching should be integrated and developed.
\end{abstract}

Keywords: Technology, Design education, Future design.

\section{INTRODUCTION}

The teaching of art and design is a complementary teaching body. In the historical process of the formation of the discipline, the study of art on human artistic behavior is to trace the earliest human activities in the initial state of the aesthetic and civilization formation process, and then to study the development history of human civilization. Relative to art teaching, the source of design teaching research should be the result of the process of industrialization. Industrialization has led to the separation of design disciplines from the art disciplines and serves the needs of industrial development. Because of the existence of this difference in cognition of the origin of the subject, it is a necessity to study how to carry out teaching design in a targeted manner in actual teaching.

\section{SOCIAL ACTIVITY FROM THE UNCONSCIOUS TO THE CONSCIOUS}

The problem of traceability in art research is generally to trace the earliest traces of human activity. Through site research, people can explore the social activities of early humans such as stone tools, rock wall paintings, pottery, etc., such as the chopper found in the Olduvai Gorge in Africa, and the primitive murals found in the caves in the Lascaux region of southern France, and Banpo human face fish-patterned colored pottery basins in Xi'an, China. Through the study of its patterns, vessel shapes and other information, the researchers can judge the characteristics of different races or national civilizations, and explore the origin of art and design.

Research has found that the earliest aesthetic consciousness is the subjective activity during the evolution from "primitive man" to "modern man (homo sapiens)", and is the human response of man in the "natural state". This kind of early art budding has special time and space requirements. In terms of time, it is a slow process of self-formation in the long history. Due to the influence of human migration and development in geographical space, this spatial selfisolation actually promotes the formation of differentiated civilization and aesthetics. Of course, this isolation is the result of low productivity in the budding stage of mankind, and this primitive economic and spatial characteristics also directly lead to the formation of the differentiation of artistic characteristics. 
In the general meaning, people regard agricultural society as the beginning of civilization for study. Dispersed human activities are gradually concentrated in specific areas, forming specific regional cultural phenomena with the characteristics of regional social groups, including the Mesopotamia civilization, the Nile delta civilization, the Yellow River civilization, etc., in order to rely on water and land resources to achieve large-scale agricultural production. As a part of social activities, especially economic activities, human aesthetic consciousness, its development and changes have also been brought into this process. Developed to the early industrial revolution period, the early scattered tribal civilization began to concentrate on the early urbanization. It is generally believed that the development of design activities was born in industrial civilization. Compared with artistic aesthetics, the starting point of time changes is relatively late, and it has the inherent characteristics of adapting to the needs of social development. Because the formation of a homogeneous space scene is beneficial to the large-scale promotion of design results, this homogenization mainly includes the use of mechanized production and the production of industrial products, such as textiles and other daily necessities. With the development and expansion of urbanization, cities are not only consumption centers, but also production centers. Therefore, all the design goals are to improve the efficiency problems that must be solved in large-scale industrial production.

In the post-industrial era, the knowledge and skills of people in the social production factors have been fully amplified through the iterative development of information technology. Artificial intelligence has been able to complete autonomous learning, and the development of aesthetics has more and more technological characteristics and is full of uncertainties.

\section{THE ESTABLISHMENT OF SOCIAL ORDER AND DESIGN LAW}

Primitive tribal totem culture is an early art form. It mainly draws symbols related to animals, plants, or clan. This is a kind of psychological worship of a specific group without knowing oneself, and has special spiritual meaning. The artistic value of religious painting, sculpture and other art forms that have developed into a class society has special class significance. Because the early aristocracy and the imperial power class mastered a large number of economic and social resources, mental control can be more conducive to strengthening social management, and directly affect personal thinking and behavior results. Therefore, artistic creation before the industrial revolution has the additional attributes of a dominant tool.

Social class will lead to class antagonism and a new social revolution. The result of the industrial revolution and the social revolution is the development of social movements such as "human rights" and "equality". In these values, it is believed that human beings are independent social individuals, and human nature is fully liberated. This development of individual needs makes diversification a necessity. The diversification of art education and design education has inherited this social ideological characteristic of the development of industrial civilization. However, the production behavior in industrial civilization forces the design behavior and aesthetics to be scientifically and systematically studied in order to maximize efficiency, such as socialist design thinking that design serves the masses. The formation of this thought process has gone from the opposition between hand-made and mechanical production during the New Arts and Crafts Movement, to the scientific and systematic production methods required by the German Manufacturing League, and then to the unity of science and art pursued by the Bauhaus. Therefore, design has the social characteristics of compromise and adapting to the development of industrial production, while artistic creation still maintains the subjective characteristics of individuality and cultural diversity.

If people say that the cultivation of aesthetic consciousness before industrial civilization is relatively closed, industrial civilization requires that the "order" of class be turned into "production efficiency", and the research and application of design laws and rules has a greater realistic economy significance.

\section{THE CONSISTENCY OF TEACHING DEVELOPMENT}

Teaching is often a process that affects society after a change of thought is formed. Teaching activities are backward and commercial activities. This can be reflected in many aspects. For example, "service design", which was born in the 1980s, originated in the field of economic activity and was proposed in the form of service design concepts at the management and marketing level. In the 1990s, it officially entered the field of design and introduced design education as a design course. Similar economic activities have always existed objectively 
as the consistent law of the impact of the underlying building on education.

In terms of specific teaching, it actually differentiates the teaching content, methods and goals of traditional art education in the development of art history. Therefore, design education can be regarded as a branch, but also as a brand-new education discipline. This is particularly prominent in the development of design education in China, that is, since the reform and opening up, the demand for design has gradually increased, and design teaching has developed vigorously, but the subject of design as a first-level subject was only determined in 2011. This phenomenon has experienced a similar development process in the design development of Europe and Japan. It is the process of making a choice between the development of traditional art forms and modern design. This development process can be a struggle of traditional art forms, that is, the transitional process of the opposition between the traditional handicrafts of the arts and crafts movement and industrial production and the slow development of design education, or it can also be a process of rapid development of inclusive modern design and design education in Japan after the war, completing the transition from traditional "intentional craftsman" to modern "design" in a relatively short time.

The traditional agricultural social education thought believes that education is for "preaching, learning, and solving puzzles", so modern art education and design education influenced by modern industrial design must be more clearly differentiated to cultivate individual independent aesthetic awareness, scientific logic and technical rules. The development of education has evolved from the inheritance of traditional craftsmanship and workshops to the infinite open space possibilities that value and apply new technologies.

In the mid-nineteenth century, from the earliest scholar Zempel Gottfried Semper (1803-1879) who studied the relationship between science, industry and art, to the later Bauhaus period, Walter - Gropius (1883-1969) proposed "art and technology, a new integration" and other design reforms, all emphasizing the rationality, logic and technology of design. This kind of thinking actually promoted the development of German industry, increased the market share of products, and directly influenced and spread to all parts of the world through Bauhaus students. Especially American modern design, which combines design and commerce efficiently, without the interference and fetters of traditional cultural factors, the development of design and design education is particularly rapid.

\section{DIFFERENCES IN GOALS AND EVALUATION CRITERION}

Human development requires time and space, as does individual development. Independent thinking formation is the common goal of art and design teaching. It's just that art education tends to study the internal changes of art creators and transform them into specific art forms in the form of works. And design education needs to study the aesthetic and social needs of people outside of itself, transform it into a professional ability, and provide design service output for the society. The difference between the teaching design goals of art teaching and design teaching results from this.

After completing the subjective expression of the individual, the work presented is first selfidentification, and then external identification. Only in this way can the perfect value be maximized. This value includes both material and ideological identification. This expression process is full of unknowns and uncertainties, and may need a specific time to trigger, and can effectively transform this kind of spiritual touch.

Design itself is thinking, a process of thinking expression, and so is teaching design. Teaching requires to train students to discover and define problems, analyze problems, summarize problems and solve problems. Design is based on the research and application of scientific laws. For example, the formation of the visual spectrum color circle comes from the divergence effect of the prism, the character of the color may be derived from the statistical law, and the printing of the color relies on accurate calculation. The laws behind it all need the support of the development of industrial technology. This is especially true of modern artificial intelligence technology, so systematic research should be inevitable in design teaching. Relatively speaking, the judgment of color in art education mainly relies on the creator's thought changes and emotional control, and subjective consciousness occupies the main position. Therefore, design thinking requires management and planning, and perceptual subjective feelings can be regarded as the result of thinking abstractly processed by people such as sociology and psychology.

Relatively speaking, the output of design works involves many stakeholders. For a single design topic and project, it is often necessary to fully consider the 
weight relationship of different stakeholders to determine the final design plan. Although it is finally presented in a visual way, this process is often more systematic and complex, and requires iterative processing of creative information over time to meet the needs of the rapid development of intellectual production in the "post-industrial era".

\section{COMPLEX FUSION}

Art and design have a lot of acquaintances, they are independent and interrelated. In addition to the Bauhaus, the development of modern design has had a significant impact on the history of design as well as Silicon Valley in the Western Bay Area of the United States, creating a post-industrial era centered on technology and knowledge. At the beginning, the main educational method of Bauhaus was the way of masters leading students, but now everything will undergo fundamental changes. The transformation of technological innovation will enter the public life scene at the fastest speed. This design methodology that changes people's lifestyles will undergo major changes from common-sense and empirical methods to experimental and abstract theoretical methods, such as: model, simulation, decision theory, system theory and other thinking modes.

There is such a case. Josef Albers (1888-1976), as a designer and artist who once taught the Bauhaus, has always pursued a systematic, orderly, experimental and concise composition, and has produced numerous works of art. In 2013, Yale University Press released an iPad version of the Albers Color Research. Through modern computer technology, users can cut and paste digitally to make their eyes more sensitive to the illusion of color. This kind of imagination can be regarded as the former laying the foundation of classic design, and the latter can rely on technology to spread this classic color theory and visual experience to the whole society through the network in the fastest way.

Of course, it may be another situation. After the war, Germany believed that the Bauhaus had been distorted by American business modernism and established the Ulm School of Design. The president Thomas Maidknado (1922-) clearly stated that design should be rational, scientific, and technical. However, due to excessive emphasis on technical factors, the design style is indifferent, lack of personality, lack of personality, monotony, etc. This shows that as far as design serves the public, design cannot be separated from art.
As a person's innate and autonomous social consciousness, artistic aesthetics is an objective fact that does not change with people's changes. However, the social space in which people live is actually a chaotic world. How to recognize oneself in chaos and how to cultivate self-recognition is actually a problem that education needs to solve, and this process is implemented through teaching design methods. Instructional design is actually beyond subjective rationality. This rationality is a series of scientific logic and rules. In art teaching design, it is actually to rationalize subjective thinking and clear self-awareness; to design teaching design, it is necessary to regularize objective facts, recognize the face of social verification, and understand the complexity of the world more calmly.

\section{TECHNOLOGY CHANGES THE FUTURE}

The technological revolution in the post-industrial era has changed the way, method and approach to learning. The way to acquire knowledge has become so simple under the impact of artificial intelligence and other technologies. However, the way and value of knowledge changing lives have undergone fundamental changes, because computers are so efficient in learning human knowledge that people have to re-examine the role and meaning of human knowledge acquisition. Perhaps the answer lies in human thinking. Why do people want to acquire knowledge? Why should people conduct aesthetic education? Can computers and artificial intelligence technologies affect and change people's aesthetic activities? The essential difference between man and machine is that man knows what he needs, not just passively receiving information, so the significance of technological progress is to serve humanity rather than to influence people's thinking and judgment of corresponding beauty. For example, painting creation completed by artificial intelligence reflects the progress of technology, but the data learns from human aesthetic laws and painting techniques. In future design education, rational thinking and perceptual subjective aesthetic feelings have become important training goals.

\section{CONCLUSION}

Design is not art. Any kind of pure art activity is a very personal thing. It is the artist's personal performance. Art creation can be done by the artist alone. Design also contains some artistic elements, but not the designer can complete it all by himself. Design requires the collaboration of many 
stakeholders. Design is a social practice closely related to human life and society itself, and this practice behavior will change with the development of society.

If people are only satisfied with the appearance of the current state of life, they will not find the various issues of human life hidden in reality, and they will not be able to move forward without reflection. According to the state of national economic development, design education units were created in Germany in 1919, the United States in 1930, and Japan around 1950. The development of design education in mainland China is all after the 1880s. Therefore, in the origin of the development of design education, although China has a long history of civilization and artistic development, modern design education as a whole lags behind the West. Therefore, some people put forward the development concept of overtaking in corners and advocated actively developing artificial intelligence and quantum computing under the new technological revolution.

Throughout the historical development of human civilization, the same artistic characteristics have been the visual symbols of a national culture. In art education, generally it is believed that nationalities are international. On the other hand, design serves others, society and the market. It is an international aesthetic rule and scientific law. Therefore, design teaching should be interdisciplinary and inclusive. The advancement of modern technology has surpassed all the technological achievements known to mankind in the past, and the changes in technology and art forms will once again undergo tremendous changes. In the future, is art and design teaching ready for the future?

\section{AUTHORS' CONTRIBUTIONS}

Yong Li wrote the manuscript, and contributed to revising and editing. Mingming Zong contributed to revising.

\section{REFERENCES}

[1] Wang Shouzhi, A History of Modern Design [M]. Beijing, China Youth Publishing Group, 2002-9. (in Chinese)

[2] Kiyoshi Miyazaki, Past, Present, Future and Sollen of Japanese Design [J]. Art \& Design, 2013 (12): 12-19.

[3] Wang Guosheng, Service Design: The Era of Chinese Design Confidence Building [J]. Design, 2020 (02): 76-81. (in Chinese)
[4] Baohaus Memorial Hall, Baohaus 1919-1933. [M]. Jiangsu: Jiangsu Phoenix Science and Technology Press, 2017-3. (in Chinese)

[5] Zong Mingming, Zong Mingming: Beyond Bauhaus - Exploring the Future [J]. Design, 2019, 32(24): 60-65. (in Chinese)

[6] Guo Chunfang, Design and Design Education Is About the Future of Mankind - Guo Chufang on Design and Art [J]. Design, 2020, 33(20): 34-37. (in Chinese) 